УДК 626.01

М.П. Саинов, Д.А. Гречко, А.Н. Акулинин

ПЕРЕЛИВНЫЕ ДАМБЫ

НА МАЛЫХ КАНАЛАХ ОБВОДНИТЕЛЬНЫХ СИСТЕМ

Приведены данные о возможных конструкциях переливных сооружений, выполненных не из бетона, а с использованием грунтов. Наиболее надежными и дешевыми из них являются дамбы из мешков с песком. Об этом говорит опыт эксплуатации таких дамб на системах обводнения торфяников, построенных в 2011-2012 гг. в Московской области. Конструкция дамб перелива из мешков должна предусматривать защиту берегов и русла в нижнем бьефе от размыва открытым и фильтрационным водными потоками. Обосновано, что запатентованные другими гидротехниками конструкции дамб перелива с креплением низового откоса геосинтетическими оболочками являются ненадежными.

Ключевые слова: грунтовые переливные плотины, водосливные плотины, геосинтетические оболочки, размыв, крепление откосов.
M.P. Sainov,

D.A. Grechko,

A.N. Akulinin

\section{OVERFLOW DAMS ON SMOLL CHANNELS OF IRRIGATION SYSTEMS}

The article has data on potential designs of overflow structures made of soil rather than concrete. The most reliable and cheap ones are dykes made of sandbags. This viewpoint is substantiated by the operation of peatland irrigation systems, constructed in the Moscow region in $2011-2012$. The construction of overflow sandbag dykes must have slope/riverbed protection structures to withstand their erosion by open and filtration flows of the downstream. Designs of overflow dykes having their downstream sides protected by geosynthetic coats, which are patented by other hydraulic engineers, have proven unreliable.

Key words: overflow earth-fill dams, water drainage dam, geosynthetic coats, water erosion, slope protection.

Идея использовать плотины из грунта для пропуска воды всегда казалась заманчивой. Уже около 5 тыс. лет назад в древнем Египте была построена первая переливная грунтовая плотина [1]. Однако при строительстве таких плотин возникает сложная проблема: водный поток, преодолевающий созданный плотиной перепад бьефов, обладая высокой скоростью, может размыть тело плотины. Чтобы этого не происходило, грунтовую плотину приходится покрывать защитным креплением. Опыт показывает, что сброс воды через грунтовые плотины без крепления можно осуществлять только в том случае, если эти плотины возведены из крупного камня, а размывы некоторой части насыпи допустимы. Об этом свидетельствует опыт пропуска строительных расходов через недостроенную плотину каменную плотину Куадат во Вьетнаме [2].

К надежности крепления водоливного тракта переливных грунтовых плотин предъявляются очень высокие требования, так как малейшее нарушение его целостности крепления ведет к разрушению грунтовой плотины. Примером может служить разрушение в 2010 г. грунтовой переливной плотины на р. Малый Узень в Саратовской области [3]. Оба откоса этой плотины, а также гребень были покрыта толстым сплошным слоем бетона, из-за нарушения целостности швов при пропуске половодья плотина была размыта.

Вероятность размыва переливной плотины из грунта всегда велика, поэтому крупных водосливных грунтовых плотин обычно не строят, ограничиваясь пропуском через грунтовые плотины только строительных расходов. Пропуск половодий путем перелива через недостроенную грунтовую плотину осуществлялся при строительстве Нурекского гидроузла [4]. При этом тело плотины было защищено специальным бетонным креплением. В 2012 г. в Киргизии была построена каменная переливная плотина Камбаратинской ГЭС-2 высотой 65 м [5]. Однако она не будет являться основным водосбросным сооружением гидроузла.

Вопросами пропуска воды переливом через грунтовые плотины в СССР занимались П.И. Гордиенко [6] и Ю.П. Правдивец $[1,7]$. Они разрабатывали ступенчатые конструкции крепления низового откоса грунтовых плотин из клиновидных 
плит, сохраняющие целостность даже при заметных деформациях тела плотины. Кроме того, ими были выполнены гидравлические исследования по поиску гидравлических режимов сопряжения бьефов за водосливными плотинами, наиболее благоприятных для работы крепления водосливного тракта. Однако гарантировать надежность работы переливных грунтовых плотин в настоящий момент нельзя.

При проектировании малых гидротехнических сооружений с низким напором и малыми скоростями течения появляется больше возможностей, чтобы воспользоваться сбросом воды переливом через грунтовые плотины, так как последствия гидродинамических аварий на таких объектах не столь значительны, а их восстановление не требует существенных финансовых затрат.

В последние десятилетия был защищен ряд кандидатских диссертаций, посвященных возможности пропуска воды через низконапорные переливные грунтовые плотины [8-10], в т.ч. под руководством доктора технических наук Ю.П. Правдивца. Предлагалось выполнять крепление низового откоса таких плотин из геосинтетических материалов. Недавно сотрудниками Самарского ГАСУ были запатентованы конструкции переливных грунтовых плотин с крутым ступенчатым низовым откосом, укрепленным геосинтетическими оболочками с анкеровкой их в тело плотины [11-13] (рис. 1).

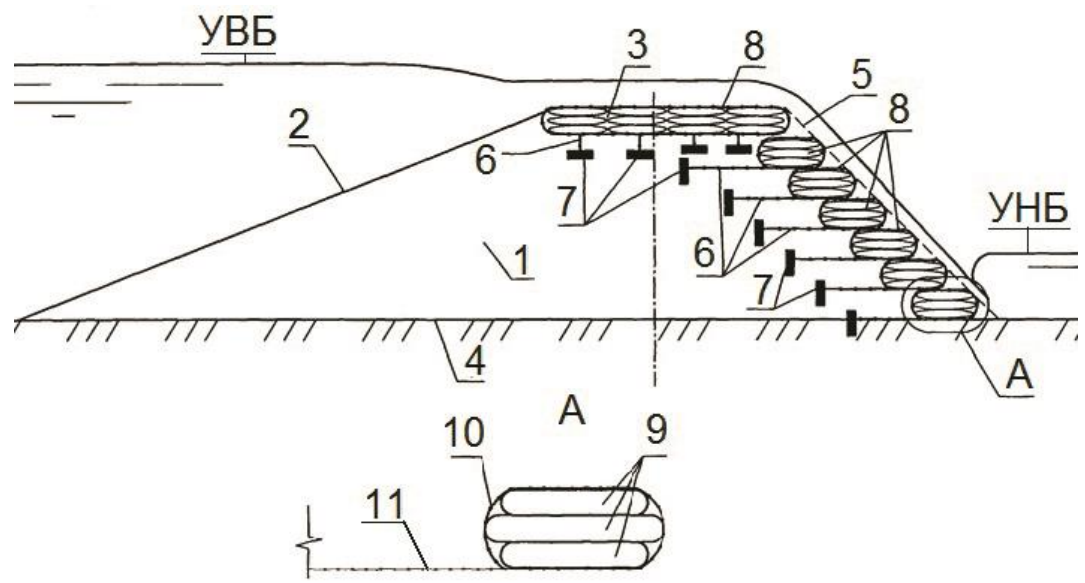

Рис. 1. Запатентованная грунтовая переливная плотина: 1 - тело переливной грунтовой плотины; 2 - верховой откос; 3 - водосливной порог; 4 - подошва плотины; 5 - низовой откос; 6 - армирующая сетка; 7 - анкерные устройства; 8 - элементы крепления; 9 - гибкие оболочки; 10 - замкнутая часть армирующей сетки; 11 протяженная часть армирующей сетки

Эти конструкции очень далеки от совершенства, а самое главное, не защищены от размыва водным потоком. Верховой откос этих плотин ничем не закреплен от водной эрозии, крепления русла в нижнем бьефе не предусматривается вовсе. Сливной откос, будучи очень крутым, подвержен деформациям, и при появлении щелей между геосинтетическими оболочками песчаный грунт тела плотины будет вымыт фильтрационным потоком.

В связи с этим авторы статьи хотели бы поделиться нашим опытом в проектировании переливных плотин из местных грунтов.

В 2011-2012 гг. авторы статьи в составе большого коллектива принимали участие в проектировании систем обводнения торфяников [14]. При этом мы столкнулись с необходимостью устройства на обводнительных каналах переливных сооружений. Эти сооружения должны были разделить канал на ряд бьефов, каждый со своим уровнем, чтобы максимально поднять уровень воды к бровке откосов. В полноводный же период эти дамбы должны были работать как водосливные плотины. Таких сооружений предполагалось устраивать много, поэтому они должны были быть максимально дешевыми.

Главный инженер проекта И.А. Седушкин предложил устраивать переливные дамбы из мешков, наполненных песком. Была разработана конструкция дамбы трапецеидального профиля с укладкой мешком в перевязку. Однако первые дамбы перелива были возведены подрядными организациями не по проекту. Эти дамбы име- 
ли прямоугольный профиль, а мешки укладывались друг на друга вертикальными столбами. Верх дамб выполнялся вровень с поверхностью окружающей территории. При отсутствии течения такое сооружения (если оно было довольно широким) было вполне устойчиво и успешно работало как водоподпорная плотина. Однако при этом берега и дно не были защищены мешками от размыва. Более того, в мешки укладывали не песок, а торф. Так как торф легче песка, то масса мешка, а, следовательно, его способность сопротивляться течению была уменьшена.

В результате первые дамбы были разрушены при переливе воды через них или в обход них (по берегам) (рис. 2, 3). С учетом опыта работы дамб перелива в натурных условиях конструкция дамб была нами усовершенствована (рис. 4-6). Было решено выполнять верховой откос более крутым (с уклоном 1), чтобы уменьшить стоимость дамбы, а низовой - более пологим (уклон 0,5), чтобы сделать дамбу более надежной. На гребне и низовом откосе дамб мешки были разложены таким образом, чтобы сформировать крепление сбросного канала и крепление русла. Мешки укладывались в перевязку. Крепление русла было сконструировано нами в виде двух слоев мешков. Для защиты грунта берегов и дна от размыва фильтрационным потоком на контакте с телом дамбы перелива был предусмотрен слой водонепроницаемой пленки.

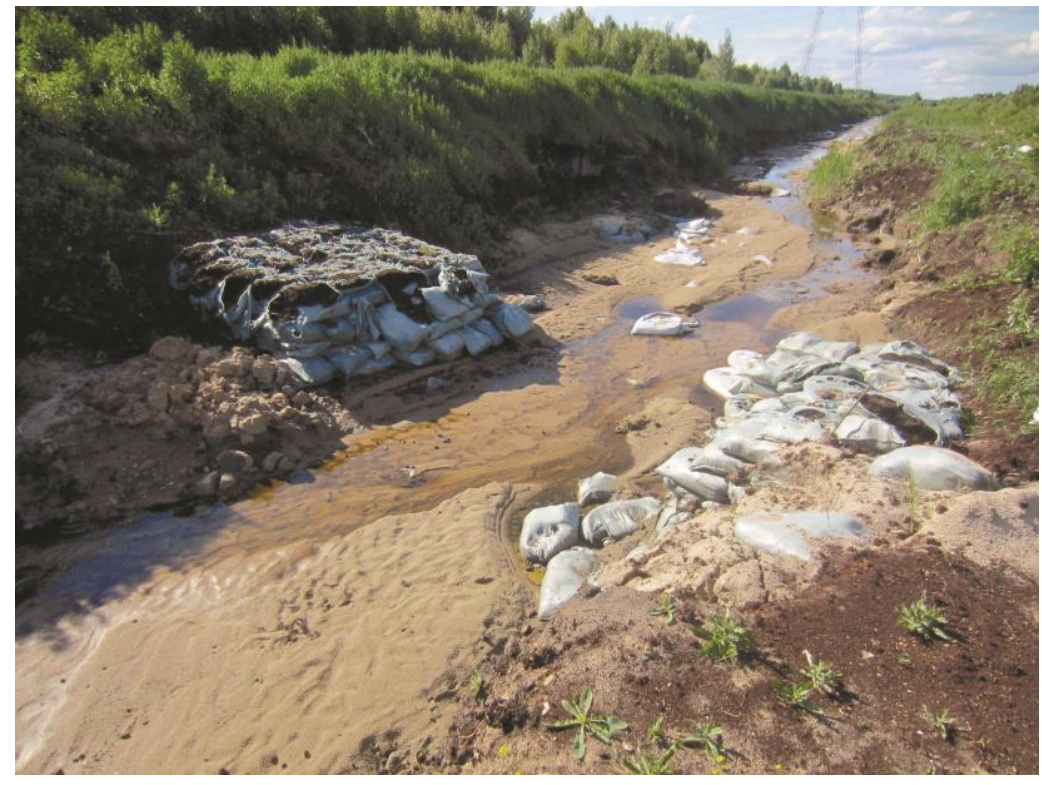

Рис. 2. Дамба, разрушенная при переливе воды через гребень

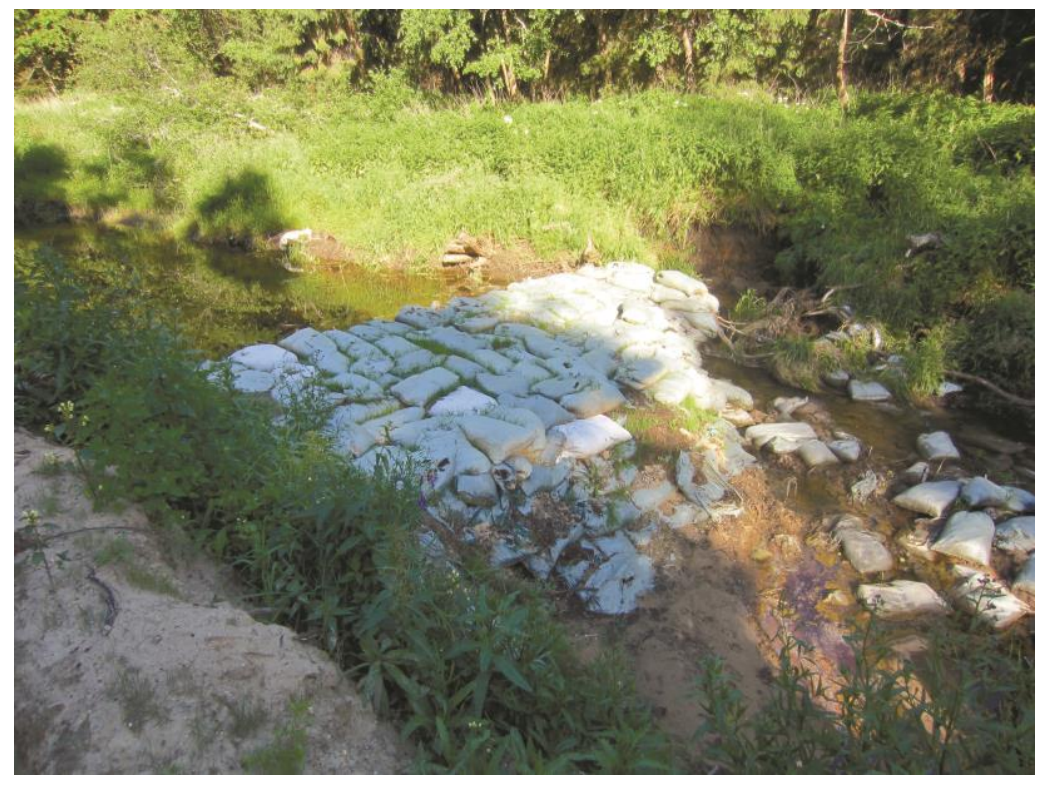

Рис. 3. Дамба, разрушенная за счет размыва левого берега 


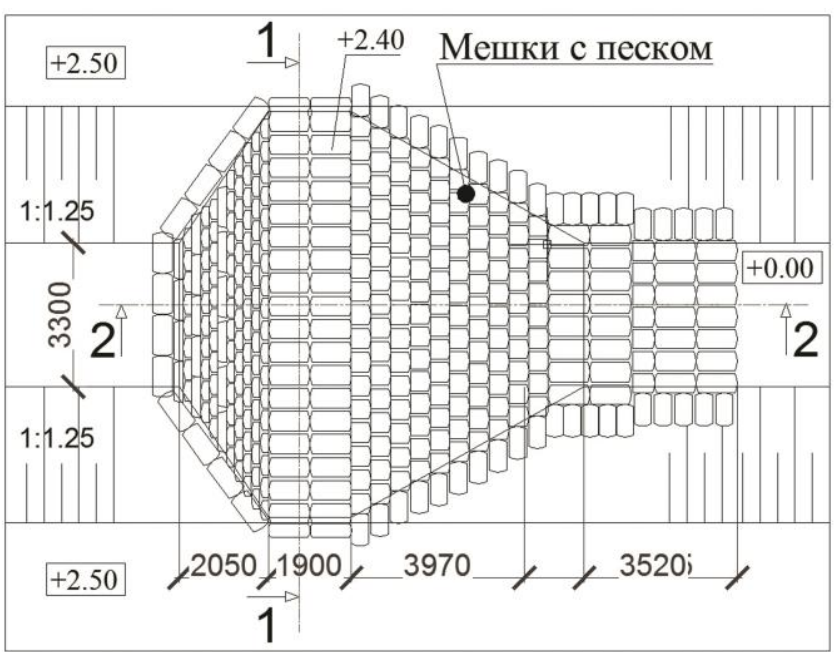

Рис. 4. План модернизированной дамбы

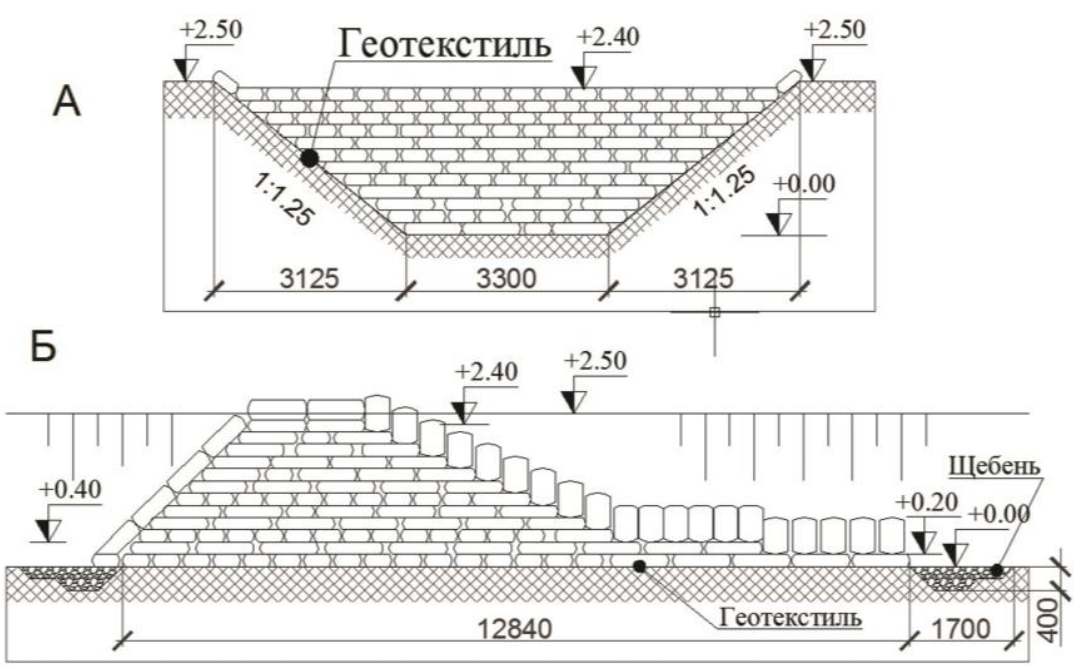

Рис. 5. Поперечный (А) и продольный (Б) разрезы модернизированной дамбы

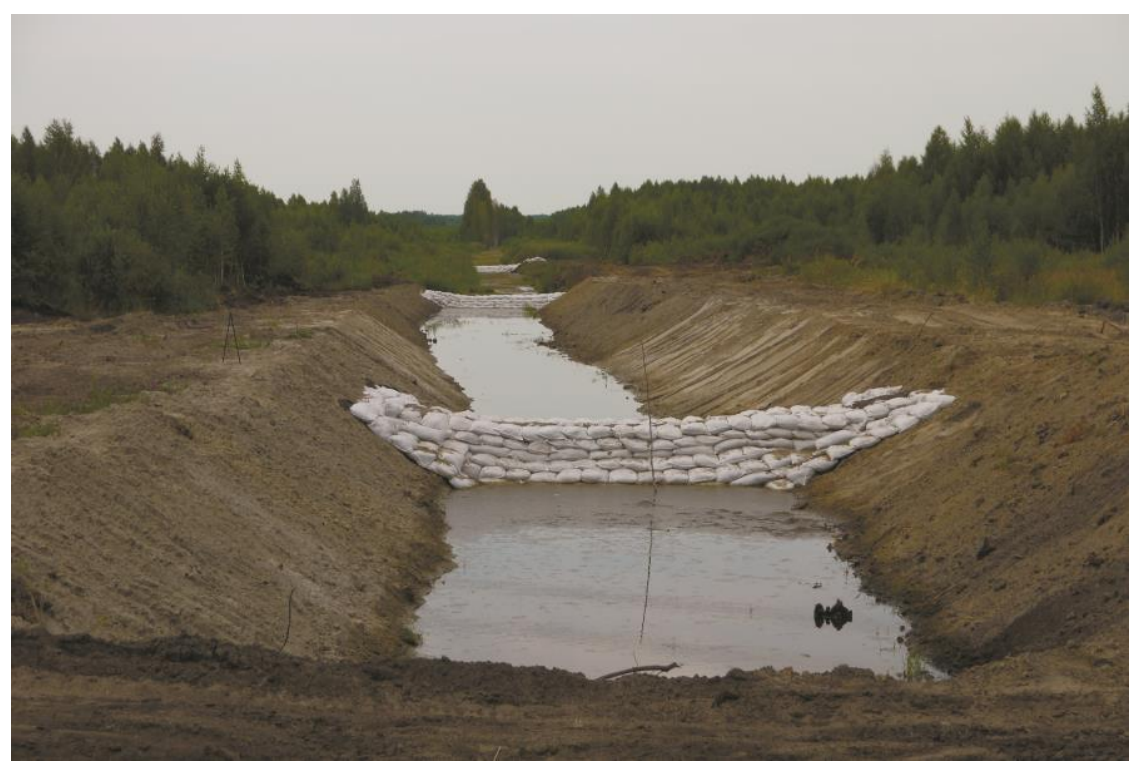

Рис. 6. Возведенные усовершенствованные дамбы

При строительстве осуществлялся контроль, чтобы мешки заполнялись песком, а не торфом. 
Опыт показал, что при небольших расходах воды запроектированные дамбы перелива высотой до 2 м работают надежно (рис. 7). Воздействия больших расходов эти дамбы пока не испытывали. Тем не менее, были отмечены смещения мешков относительно своего первоначального положения. Так как такие дамбы представляют собой временные сооружения, их повреждение или даже разрушение не столь опасный факт.

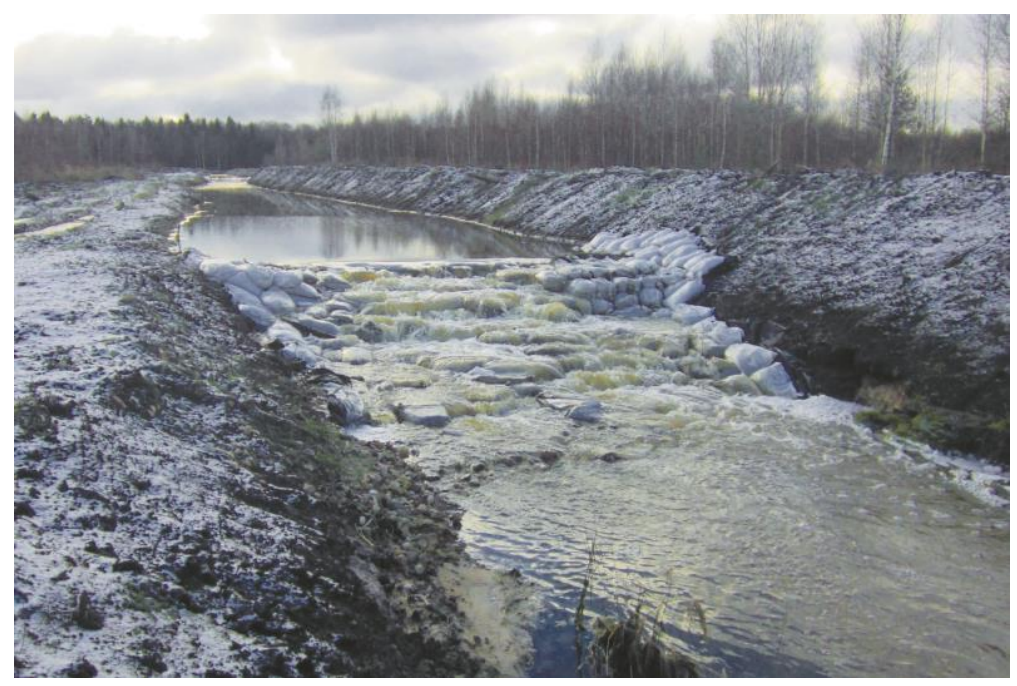

Рис. 7. Эксплуатируемая дамба перелива из мешков с песком

Мешки, заполненные грунтом, могут, кроме того, с успехом использоваться для крепления берегов от размыва. Такое крепление подвижное и может выдерживать большие деформации без разрушения.

К недостаткам дамб перелива из мешков относятся требуемый большой объем грунта и их недолговечность. Для создания небольших по высоте дамб перелива было предложено использовать габионы и матрасы Рено. Простейшая конструкция представляет грунтовую насыпь, накрытую матрасом Рено (рис. 8), но при этом им должны быть накрыты не только грунтовая насыпь, но окружающие откосы канала, по которым будет течь вода. Обязательным требованием к конструкции такой дамбы является необходимость укладки геотекстиля между камнем и грунтом во избежание вымыва последнего.

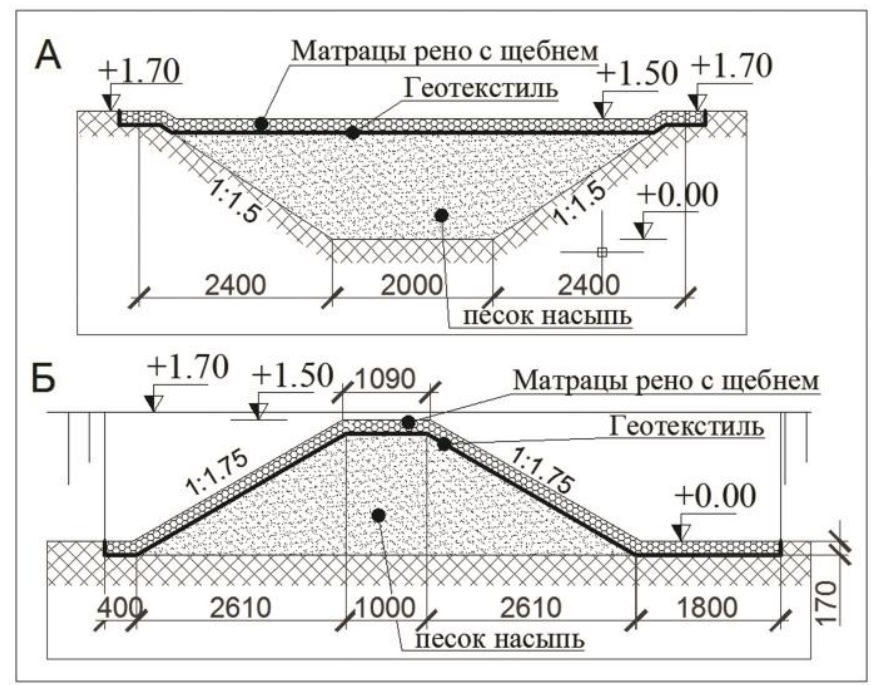

$a$

6

Рис. 8. Поперечный ( $а$ ) и продольный (б) разрезы дамбы из матрасов Рено

При большей высоте дамб может применяться дамба перелива из габионов следующей конструкции (рис. 9). Поперек канала на некотором расстоянии друг от друга устанавливаются два габиона, заполненных камнем. Так как дамба перелива 
служит не только водопропускным сооружением, но и водоподпорным, то в такой дамбе необходим противофильтрационный элемент. Им может служить мелкозернистый грунт. Чтобы этот грунт не вымывался через поры камня, грунт должен быть «обернут геотекстилем». Сверху противофильтрационный элемент может быть защищен от размыва матрасом Рено. Очень важным является крепление русла за дамбой перелива. Должен быть устроен водобой, например, с помощью матраса Рено.
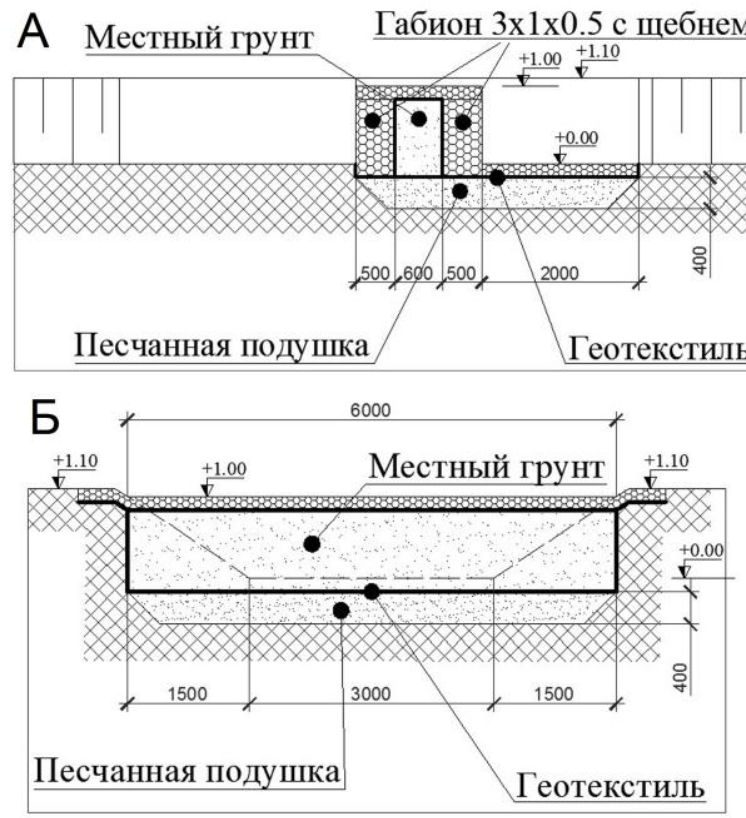

Рис. 9. Продольный ( $a)$ и поперечный (б) разрезы дамбы из габионов

Достоинством дамб перелива из габионов и матрасов Рено является то, что они хорошо вписывается в природную среду, не выделяются в ней как искусственные сооружения. Они, как и дамбы из мешков, легко «приспосабливаются» к изменениям внешней среды. Эти сооружения более защищены от водной эрозии. Однако они дороже по стоимости, чем переливные дамбы из мешков с песком.

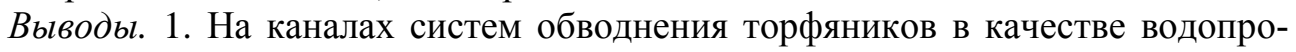
пускных и одновременно водоподпорных сооружений перспективным является возведение переливных дамб с использованием местных грунтовых материалов. Защита грунтов от размыва может осуществляться либо с помощью мешков, заполненных грунтом, либо с помощью сетчатых ящиков, заполненных камнем. Подобное гибкое крепление хорошо «приспосабливается» к деформациям насыпи.

2. При проектировании дамб перелива из мешков важно обеспечить следующие условия:

борта должны быть надежно защищены от размыва бортиком из мешков,

дно водотока за дамбами перелива должно быть закреплено от размыва. Это можно сделать в виде крепления из двух слоев мешков,

на контакте между дамбами перелива и грунтом берегов и дна канала должна быть уложена водонепроницаемая пленка, которая его защитит от размыва.

3. Переливные дамбы, полностью выполненные из мешков с песком, являются более надежными, чем дамбы, в которых из заполненных грунтом геосинтетических оболочек выполнено только крепление низового откоса. В последних крепление откоса под воздействием потока воды будет перемещаться, обнажая тело плотины, не защищенное от размыва, что может привести к аварии. Опыт эксплуатации переливных дамб из мешков с песком говорит о том, что они вполне жизнеспособны.

Переливные дамбы могут с успехом строиться с применением габионов и матрасов Рено. Главное условие жизнеспособности таких дамб - это защищенность берегов и дна канала от водной эрозии. Однако такие переливные дамбы будут дороже, чем переливные дамбы из мешков с песком. 
1. Правдивеи Ю.П. Ступенчатые водосбросы в мировой и отечественной практике // Гидротехническое строительство. 1993. № 10. С. 28-32.

2. Пехтин В.А., Беллендир Е.Н., Радченко В.Г. Современный этап развития водного хозяйства и гидроэнергетики Вьетнама // Гидротехническое строительство. 2011. № 2. С. $46-53$.

3. Приказ Федеральной службы по экологическому, технологическому и атомному надзору от 3 июня 2011 г. № 278 «Об утверждении Годового отчета о деятельности Федеральной службы по экологическому, технологическому и атомному надзору в 2010 году».

4. Гидротехнические сооружения / под ред. Л.Н. Рассказова, М. : Изд-во АСВ, 2011.

5. Корчевский В.Ф., Обополь А.Ю. О проектировании и строительстве Камбаратинских гидроэлектростанций на р.Нарыне в Киргизской Республике // Гидротехническое строительство. 2012. № 2. С. 2-12.

6. Гордиенко П.И. Водосливные плотины из каменной наброски // Гидротехническое строительство. 1944. № 3. С. 7-13.

7. Правдивеи Ю.П. Индустриальные конструкции грунтовой водосливной плотины // Гидротехническое строительство. 1987. № 12. С. 15-18.

8. Шрестха Субарна Дас Научные основы расчетного обоснования, проектирования и строительства переливных грунтовых плотин : дисс. ... канд. техн. наук. М., 1998.

9. Поудиал Басу. Научно-расчетное и экспериментальное обоснование применения грунтовой переливной плотины в условиях высокой сейсмичности Непала : дисс. ... канд. техн. наук. М., 2003. 120 с.

10. Родионов М.В. Грунтовые переливные плотины с низовым откосом, сформированным геосинтетическими оболочками : автореф. ... канд. техн. наук. Самара, 2012.

11. Бальзанников М.И., Родионов М.В. Результаты исследования грунтовой переливной плотины со ступенчато-криволинейным низовым откосом // Вестник МГСУ. 2012. № 2. C. $70-76$.

12. Бальзанников М.И., Родионов М.В. Патент РФ 2432432, МПК Е02В7/06. Переливная грунтовая плотина. Заявка № 2010126843; опубл. 2011, Бюл. № 30.8 с.

13. Бальзанников М.И., Родионов М.В. Патент РФ 100527, МПК Е02В7/06. Переливная грунтовая плотина. Заявка № 2010126899. опубл. 2010, Бюл. № 35.2 с.

14. Акулинин А.Н., Саинов М.П. Опыт проектирования малых гидротехнических сооружений для систем обводнения торфяников: научное издание Минообрнауки РФ и ФГБОУ ВПО «МГСУ». М. : МГСУ, 2012. С. 494—498.

\section{REFERENCES}

1. Pravdivets Yu.P. Stupenchatye vodosbrosy v mirovoy i otechestvennoy praktike [Stepshaped Basins in the International and Domestic Practice]. Gidrotekhnicheskoe stroitel'stvo [Hydraulic Engineering Construction]. 1993, no. 10, pp. 28 - 32.

2. Pekhtin V.A., Bellendir E.N., Radchenko V.G. Sovremennyy etap razvitiya vodnogo khozyaystva i gidroenergetiki V'etnama [Present-day Stage of Development of the Water Economy and Hydraulic Power Engineering of Viet Nam]. Gidrotekhnicheskoe stroitel'stvo [Hydraulic Engineering Construction]. 2011, no. 2, pp. 46 - 53.

3. Prikaz Federal'noy sluzhby po ekologicheskomu, tekhnologicheskomu i atomnomu nadzoru ot 3 iyunya 2011 g. № 278 «Ob utverzhdenii Godovogo otcheta o deyatel'nosti Fede-ral'noy sluzhby po ekologicheskomu, tekhnologicheskomu i atomnomu nadzoru v 2010 godu» [Decree of the Federal Service for Ecological, Technological and Atomic Supervision of June 3, 2011 no. 278 "On Approval of the Annual Report of Operations of the Federal Service for Ecological, Technological and Atomic Supervision in 2010"].

4. Rasskazov L.N., editor. Gidrotekhnicheskie sooruzheniya [Hydraulic Engineering Structures]. Moscow, ASV Publ., 2011.

5. Korchevskiy V.F., Obopol' A.Yu. O proektirovanii i stroitel'stve Kambaratinskikh gidroelektrostantsiy na r. Naryne v Kirgizskoy Respublike [On Design and Construction of Kambarati Hydraulic Power Plants on the Naryn River in Kyrgyzstan]. Gidrotekhnicheskoe stroitel'stvo [Hydraulic Engineering Construction]. 2012, no. 2, pp. 2 - 12.

6. Gordienko P.I. Vodoslivnye plotiny iz kamennoy nabroski [Drop-inlet Rockfill Dams]. Gidrotekhnicheskoe stroitel'stvo [Hydraulic Engineering Construction]. 1944, no. 3, pp. 7 - 13.

7. Pravdivets Yu.P. Industrial'nye konstruktsii gruntovoy vodoslivnoy plotiny [Industrial Structures of Earth Drop-inlet Dams]. Gidrotekhnicheskoe stroitel'stvo [Hydraulic Engineering Construction]. 1987, no. 12. 
8. Shrestkha Subarna Das. Nauchnye osnovy raschetnogo obosnovaniya, proektirovaniya $i$ stroitel'stva perelivnykh gruntovykh plotin [Scientific Fundamentals of Analytical Substantiation, Design and Construction of Overfill Earth Dams]. Moscow, 1998.

9. Poudial Basu. Nauchno-raschetnoe $i$ eksperimental'noe obosnovanie primeneniya gruntovoy perelivnoy plotiny $v$ usloviyakh vysokoy seysmichnosti Nepala [Scientific, Analytical and Experimental Substantiation of Application of Overfill Earth Dams in the Conditions of High Seismicity of Nepal]. Moscow, 2003, 120 p.

10. Rodionov M.V. Gruntovye perelivnye plotiny s nizovym otkosom, sformirovannym geosinteticheskimi obolochkami [Overfill Earth Dams Having Outer Slopes Made of Geosynthetic Coats]. Samara, 2012.

11. Bal'zannikov M.I., Rodionov M.V. Rezul'taty issledovaniya gruntovoy perelivnoy plotiny so stupenchato-krivolineynym nizovym otkosom [Results of the Research of the EarthFilled Overflow Dam with a Curving and Step-shaped Downstream Section], Vestnik MGSU [Proceedings of Moscow State University of Civil Engineering]. 2012, no. 2, pp. $70-76$.

12. Bal'zannikov M.I., Rodionov M.V. Patent RF 2432432, MPK E02B7/06. Perelivnaya gruntovaya plotina. Zayavka № 2010126843; opubl. 2011, Byul. № 30. [RF Patent 2432432, MPK E02B7/06. Overfill Earth Dam. Application no. 2010126843, published in 2011, Bulletin no. 30]. 8 p.

13. Bal'zannikov M.I., Rodionov M.V. Patent RF 100527, MPK E02B7/06. Perelivnaya gruntovaya plotina. Zayavka № 2010126899, opubl. 2010, Byul. № 35. [RF Patent 100527, MPK E02B7/06. Overfill Earth Dam. Application no. 2010126899, published in 2010, Bulletin no. 35]. 2 p.

14. Akulinin A.N., Sainov M.P. Opyt proektirovaniya malykh gidrotekhnicheskikh sooruzhenik dlka sistem obvodnenika torfkanikov [Design experience small hydraulic engineering projects of peatland irrigation systems]. Nauchnoe izdanie MinoObrNauki RF i FGBOU VPO "MGSU» [Scientific publication ministry of education and science of the Russian Federation and MSUCE]. Moscow, MSUCE, 2012, pp. 494-498.

Поступила в редакциюю в мае 2013 г.

Об авторах: Саинов Михаил Петрович, кандидат технических наук, доцент, доцент кафедры гидротехнических сооружений, ФГБОУ ВПО «Московский государственный строительный университет» (ФГБОУВПО «МГСУ»), 129337, г. Москва, Ярославское шоссе, д. 26, mp_sainov@mail.ru;

Гречко Дмитрий Андреевич, студент Института гидротехнического и энергетического строительства, ФГБОУ ВПО «Московский государственный строительный университет» (ФГБОУВПО «МГСУ»), 129337, г. Москва, Ярославское шоссе, д. 26, dmitrygrek@gmail.com;

Акулинин Антон Николаевич, студент Института гидротехнического и энергетического строительства, ФГБОУ ВПО «Московский государственный строительный университет» (ФГБОУВПО «МГСУ»), 129337, г. Москва, Ярославское шоссе, д. 26, saleric @bk.ru
About the authors: Sainov Mihail Petrovich, phD, assistant of professor, Moscow State University of Civil Engineering (MSUCE), 26 Jaroslavskoe shosse street, Moscow, 129337, Russian Federation, mp_sainov@mail.ru;

Grechko Dmitry Andreevich, student, Moscow State University of Civil Engineering (MSUCE), 26 Jaroslavskoe shosse street, Moscow, 129337, Russian Federation, dmitrygrek@gmail.com;

Akulinin Anton Nikolaevich, student, Moscow State University of Civil Engineering (MSUCE), 26 Jaroslavskoe shosse street, Moscow, 129337, Russian Federation, saleric@bk.ru

Для цитирования:

Саинов М.П., Гречко Д.А., Акулинин А.Н. Переливные дамбы на малых каналах обводнительных систем [Электронный ресурс] // Строительство: наука и образование. 2013. Вып. 2. Ст. 2. Режим доступа: http://www.nso-journal.ru.

For citation:

Sainov M.P., Grechko D.A Akulinin A.N. Perelivnye damby na malykh kanalakh obvodnitel'nykh sistem [Overflow dams on smoll channels of irrigation systems]. Stroitel'stvo: nauka i obrazovanie [Construction: Science and Education], 2013, no. 2, paper 2. Available at: http://www.nso-journal.ru. 